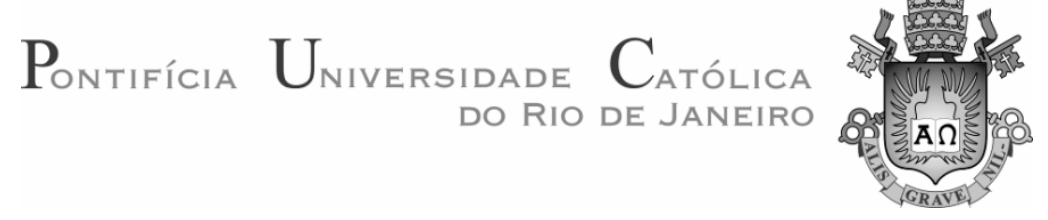

Antonio José Vieira de Queirós Campos

\author{
Platão, Leitor de Aristófanes \\ Elementos para uma leitura intertextual \\ e proléptica da Apologia de Sócrates
}

Dissertação de Mestrado

Dissertação apresentada ao Programa de Pósgraduação em Filosofia da PUC-RIO como requisito parcial para obtenção do grau de Mestre em Filosofia. Aprovada pela Comissão Examinadora abaixo assinada.

Orientadora: Profa ${ }^{a}$ Dr ${ }^{a}$ Irley Fernandes Franco 


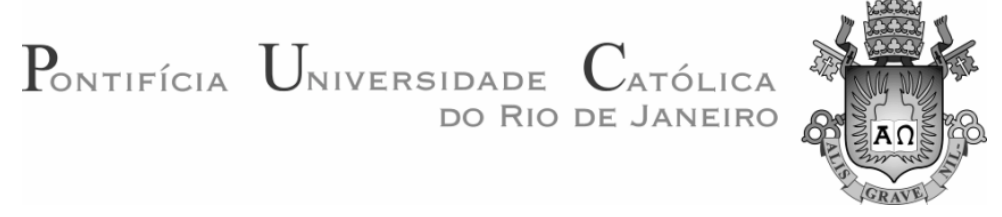

Antonio José Vieira de Queirós Campos

\section{Platão, Leitor de Aristófanes \\ Elementos para uma leitura intertextual e proléptica da Apologia de Sócrates}

Dissertação de Mestrado

Dissertação apresentada ao Programa de Pósgraduação em Filosofia da PUC-RIO como requisito parcial para obtenção do grau de Mestre em Filosofia. Aprovada pela Comissão Examinadora abaixo assinada.

Profa. Irley Fernandes Franco Orientadora

Departamento de Filosofia, PUC-Rio

Profa. Maura Iglésias

Departamento de Filosofia, PUC-Rio

Prof. James Arêas

Departamento de Filosofia, UERJ

Profa . Denise Berruzo Portinari Coordenadora Setorial do Centro de Teologia e Ciências, PUC-Rio

Rio de Janeiro, 14 de abril de 2011 
Todos os direitos reservados. É proibida a reprodução total ou parcial do trabalho sem autorização do autor, do orientador e da universidade.

\section{Antonio José Vieira de Queirós Campos}

Graduou-se em Filosofia pela Faculdade de Filosofia da PUC-Rio em 2001. Lecionou cursos de Filosofia Antiga e Tragédia Grega na CCE, Coordenação Central de Extensão, em 2008 e 2009. Atualmente dá aulas de Grego Clássico no mestrado de Filosofia da PUC-Rio.

Ficha Catalográfica

Campos, Antonio José Vieira de Queirós

Platão, leitor de Aristófanes : elementos para uma leitura intertextual e proléptica da Apologia de Sócrates I Antonio José Vieira de Queirós Campos ; orientador: Irley Fernandes Franco. - 2011.

302 f. ; $30 \mathrm{~cm}$

Dissertação (mestrado)-Pontifícia Universidade Católica do Rio de Janeiro, Departamento de Filosofia, 2011.

Inclui bibliografia

1. Filosofia - Teses. 2. Platão. 3. Aristófanes. 4. Intertextualidade. 5. Comédia antiga. 6. Prolepse. 7. Ironia. I. Franco, Irley Fernandes. II. Pontifícia Universidade Católica do Rio de Janeiro. Departamento de Filosofia. III. Título. 
Para meus queridos esposa e filhos, Martha, Matheus e Hugo. 


\section{Agradecimentos}

À minha orientadora, Prof ${ }^{a}$. Irley Fernandes Franco, pelo seu constante estímulo, disponibilidade, conselhos e carinho.

À Prof ${ }^{\mathrm{a}}$. Maura Iglésias, por ter me apresentado Platão e me encorajado ao estudo do Grego Clássico.

Ao Prof. James Arêas, pelo interesse no assunto, solidariedade e pela honrosa amizade.

À Prof ${ }^{a}$ Maria Inês Senra Anachoreta, pela sempre agradável interlocução.

Aos meus alunos de Grego da PUC-Rio, pelos frequentes debates e pela paciência de me ouvir.

À Vice-Reitoria para Assuntos Acaêmicos, pela concessão de bolsa de isenção para a realização do mestrado em filosofia.

Aos meus queridos amigos de mestrado e doutorado em filosofia da PUC-Rio, que, de algum modo, acompanharam o desenvolvimento deste trabalho. 


\section{Resumo}

Platão, Leitor de Aristófanes (Elementos para uma leitura intertextual e proléptica da Apologia de Sócrates) mostra a dívida platônica e suas consequências literário-político-filosóficas com a herança cultural e "literária" de seu tempo, sobretudo a proveniente da Comédia Antiga, ressaltando, muito especialmente, a contribuição de Aristófanes na configuração dramático-fillosófica da obra inicial de Platão. Dá ênfase à dimensão de intertextualidade inerente ao corpus platonicum. Examina criticamente a tese hermenêutica de Charles Kahn, fundada em seu conceito de prolepse, tentando ampliar sua aplicação a um número maior de diálogos platônicos e incorporando a essa noção elementos literário-políticos. Finalmente, dá atenção especial à interpretação de três temas concebidos como cruciais para uma compreensão intertextual e proléptica da obra considerada como inaugural na carreira platônica de escritor e filósofo, a Apologia de Sócrates: o episódio do oráculo de Delfos, o significado do elenco socrático e de sua aplicação e a diferenciação entre a chamada "ironia socrática" e uma possível "ironia platônica".

\section{PALAVRAS-CHAVE}

Platão, Aristófanes, intertextualidade, Comédia Antiga, prolepse, ironia. 


\section{Abstract}

Plato, Reader of Aristophanes (Elements for an intertextual and proleptic reading of The Apology of Socrates) shows the platonic debt to the cultural and literary heritage of his time, mostly to Ancient Comedy, highlighting Aristophanes contribution to the dramatic and philosophical configuration of Plato's initial work. It stresses the intertextual dimension inherent to the platonicum corpus. Another goal is a critical inquiry into the hermeneutic thesis by Kahn, founded on his concept of prolepsis, with the intention of broadening its appliccation to a larger number of platonic dialogues through incorporating literary and political elements to this notion. Finally, special attention is given to the interpretation of three crucial themes to an intertextual and proleptic comprehension of what is considered the first dialogue of the platonic career as writer and philosopher, the Apology of Socrates: the Delphi oracle episode, the socratic elenchus' significance and application and the distinction between the so-called "socratic irony" and a possible "platonic irony".

\section{KEYWORDS}

Plato, Aristophanes, intertextuality, Ancient Comedy, prolepsis, irony. 


\section{Sumário}

1. Introdução 10

2. Questões preliminares 21

2.1. Tentativa de contextualização instrumental, ad hoc, 21 para os propósitos deste trabalho, do ambiente político e "literário" da Atenas do século $\mathrm{V}$ a.C.

2.2. A questão socrática: perplexidades do exame das quatro fontes - Aristófanes, Xenofonte, Platão e Aristóteles

2.3. O Sócrates dos diálogos de Platão - visão evolutiva 56 contra visão unitária

3. Argumentos contra duas teses incidentais de Kahn

3.1. Argumentação contra a historicidade da Apologia, proposta por Kahn

3.2. Argumentação contra a subestimação de Aristófanes como fonte do Sócrates de Platão

4. Fixação da caricatura aristofânica como ponto de partida de Platão para a concepção do seu Sócrates da Apologia 5. Justificação da necessidade de uma interpretação proléptica ampliada de Platão numa perspectiva políticoliterária, em diálogo com Aristófanes

5.1. Notas sobre a evolução proléptica do Sócrates platônico, da erística à dialética

5.2. República, Livro X: fim do itinerário proléptico

5.3. O nexo profundo entre o Belo e o Bom e o diálogo

socrático como sua forma literária necessária

6. Discussão de temas-chave para a interpretação proléptica e intertextual da Apologia

6.1. A questão do oráculo, argumentação histórico234 filosófica (revisão dos limites divino/ humano) 
6.2. A questão do elenco, argumentação filológica- 252 filosófica

6.3. A ironia socrática como método e a ironia platônica 266 como comicidade, argumentação estético-filosófica

7. Conclusão 286

8. Referências bibliográficas 293 